\title{
EFFECT OF USE DIFFERENT PELLET LENGTHS ON PERFORMANCE OF BROILER CHICKEN
}

\author{
Dr. Zelal Ahmad Alsaftli ${ }^{1}$
}

1Ph.D at Animal Production Department, Faculty Of Agriculture, University Of Hama, Hama, Syria

E-mail ID: Zelal.Alsaftli@Hama-univ.edu.sy

\begin{abstract}
The objective of this study was to evaluate the effect of Different pellet lengths on digestive tract development and performance of broilers. In this experiment 300 day old broiler chicks (Ross-308) were used in a completely randomized design for 42 days in two periods include grower (10-21d) and finisher (22-42 d) with 4 treatments in 3 replicates and 25 chicks in each replicate. The length levels of inclusion pellet was based on $\mathrm{T} 1=3 \mathrm{~mm}$ (control group), $\mathrm{T} 2=4 \mathrm{~mm}, \mathrm{~T} 3=5 \mathrm{~mm}$, and $\mathrm{T} 4=6 \mathrm{~mm}$. While pellet diameter was same to all treatments $=4.5 \mathrm{~mm}$. From 0 to $9 \mathrm{~d}$ of age, all birds were offered a common starter diet pelleted with a 3-mm diameter die and 3-mm length.
\end{abstract}

According to the results, mortality during the performance experiment was negligible. During the grower period $(10$ to $21 \mathrm{~d})$, weight gain was influenced $(P<0.05)$ by pellet length, with gain of birds fed pellets of $6-\mathrm{mm}$ length being greater than that fed 3-mm length pellets (control group). Neither effects of pellet length were insignificant $(P>0.05)$ for feed intake. Feeding longer pellets decreased $(P<0.05)$ feed per gain compared to control brids. And there was no effect of pellet diameter for feed per gain .

During the finisher (22 to $42 \mathrm{~d}$ ) and whole trial (10 to $42 \mathrm{~d}$ ) periods, effects of pellet length were insignificant $(P>0.05)$ for weight gain and feed intake. A significant $(P<0.05$, finisher period; $P<0.05$, whole trial period) pellet length effect was observed for feed per gain with increasing pellet length from 3- to 6-mm.

There were significant effects of pellet length $(P<0.05)$ for relative length of duodenum. Increasing pellet length reduced the relative length of duodenum. Neither effects were insignificant $(P>0.05)$ for relative length of jejunum, ileum and small intestine. While the effect of pellet length for the relative length of caeca $(P<0.05)$ was observed. Sothat increasing pellet length reduced the relative length of caeca. And effect of pellet length was observed for relative weight of proventriculus $(P<0.05)$, with birds fed $3-\mathrm{mm}$ length pellets having heavier proventriculus compared to those fed 4,5,6-mm length pellets. And effects were insignificant $(P>0.05)$ for relative weight of gizzard, small intestine and 
caeca. Overall, the data suggest that that using longer pellet lengths may have an additive effect on pellet quality.

Key words: pellet, performance, digestive tract, broilers. 


\section{Introduction}

The majority of broilers are fed pelleted diets. Feeding pelleted diets results in an improvement in weight gain and feed conversion compared to feeding mash diets.

Many feed ingredients, especially cereal grains, are ground before they are incorporated into poultry diets. A smaller particle size is associated with a larger surface area of the grain, possibly resulting in higher digestibility in poultry due to a greater interaction with digestive enzymes in the gastrointestinal tract (Goodband et al., 2002).

The importance of physical quality of pellets in improving growth responses is well recognised in the broiler industry (Moritz et al., 2001; Behnke and Beyer, 2002; Moritz et al., 2003; Cutlip et al., 2008; Hott et al., 2008; Corzo et al., 2011). Moreover, feed is too expensive to waste; so pellet quality has an economic value (Löwe, 2005). To create high physical quality pellets, a better understanding of factors affecting pellet quality is necessary. According to Reimer (Cited in Behnke, 2001), pellet quality depends proportionally on the following factors: $40 \%$ feed formulation, $20 \%$ feed particle size, $20 \%$ steam-conditioning, 15\% pellet die specification, and 5\% cooling and drying process. Feed ingredients have a marked impact on pellet quality. Achieving high quality pellets through manipulating diet formulation, however, has become relatively difficult due to the fact that least-cost diet formulation is the primary concern of the poultry nutritionists as well as the use of concepts such as ideal protein in feed formulations which eliminates the need for high dietary protein levels.

Feed physical form is one of most important factors, which confound the effect of particle sizes on digestibility of nutrients and growth performance. Pelleting is the most preferred form of diet for broiler chickens, during the starter and grower periods, showing an increased feed intake and weight gain and improved feed to gain ratio (Calet, 1965). Also, pelleting feed for broilers can improve AME and apparent metabolizability of organic matter (Kilburn \& Edwards, 2001; Svihus et al., 2004).

Published data on the effect of feed particle size on pellet quality are contradictory (Thomas et al., 1998; Dozier, 2003; Svihus et al., 2004; Amerah et al., 2007). In general, coarsely-ground particles are believed to compromise the pellet quality, although there is no objective evidence to support this claim (Amerah et al., 2007).

It has been postulated that birds select an appropriate feed size according to variation of their oral cavity, and birds have difficulty in eating particles that are bigger or much smaller than the size of the beak (Moran, 1982). Nir et al. (1995) suggested that particle digestion within the proximal small intestine is slower when particles are bigger, resulting in more peristaltic movements and maybe a better utilization of the nutrients. Thus, the consumption of diets with different characteristics may not be similar and may have a direct effect on the morphological structure of the digestive system of the birds, such that any alteration in the structure of the feed might have a significant effect on performance by restricting or making some nutrients unavailable (Macari et al., 1994). For example, birds that eat fiber and/or coarse food tend to have a longer gastrintestinal tract (Denbow, 2000). On the other hand, both gizzard atrophy (Nir et al., 1994a; Nir et al., 1995; Magro, 1999) and a discrete intestinal hypertrophy (Nir et al., 1994a) have been observed 
when finely ground food was fed to the birds. Moreover, younger birds prefer a smaller particle size while older ones select a bigger particle size (Portella et al., 1988). According to these observations, birds fed a smaller pellet size could feel comfortable eating and consequently these birds could spend less energy for eating. Thus, birds fed pelleted diets increase the net energy value due to increasing resting behavior and decreasing time eating (McKinney \& Teeter, 2004; Skinner-Noble et al.,2005).

Based on above discussion, it was hypothesised that manipulation of pellet size (diameter and length) may provide another potential approach to improve pellet quality at low conditioning temperatures. To test this hypothesis, the present experiment was designed to examine the effect of pellet diameter and length on Performance and digestive tract development of broilers.

\section{Materials and Methods :}

\section{Diets:}

The study was used in a completely randomized design to evaluate the effects of four pellet lengths $(3,4,5$ and $6-\mathrm{mm})$, without changing pellet diameter that it was same to all treatments $=4.5 \mathrm{~mm}$. Broiler grower (d 10 to 21) and finisher (d 22 to 42) diets were formulated to meet the Ross 308 strain recommendations for major nutrients (Ross, 2007; Table 1).

Each of grower and finisher diets was then subjected to four pelleting treatments:

1. pelleted with a $4.5-\mathrm{mm}$ die and 3-mm length (TO) as a control diet.

2. pelleted with a $4.5-\mathrm{mm}$ die and 4-mm length (T1).

3. pelleted with a $4.5-\mathrm{mm}$ die and $5-\mathrm{mm}$ length (T2).

4. pelleted with a 4.5-mm die and 6-mm length (T3).

All diets were steam-conditioned at $60^{\circ} \mathrm{C}$ for 30 seconds and pelleted using a pellet mill capable of manufacturing $200 \mathrm{~kg}$ of feed/h. 
Table 1. Composition and calculated analysis of the basal diets \%

\begin{tabular}{|c|c|c|}
\hline Items & 0 to $21 d$ & 22 to $42 d$ \\
\hline \multicolumn{3}{|l|}{ Ingredients (\%) } \\
\hline Corn & 55.45 & 58.28 \\
\hline Soybean meal & 38.95 & 33.91 \\
\hline Soybean oil & 1.43 & 4 \\
\hline Sodium chloride & 0.22 & 0.2 \\
\hline Dicalcium phosphate & 2.20 & 2.0 \\
\hline Limestone & 1.00 & 0.9 \\
\hline DL-methionine (99\%) & 0.25 & 0.21 \\
\hline Cholin HCL & 0.10 & 0.10 \\
\hline Trace mineral-vitamin 1 & 0.10 & 0.10 \\
\hline Salt Nacl & 0.30 & 0.30 \\
\hline \multicolumn{3}{|l|}{ Calculated analysis } \\
\hline ME (kcal/kg) & 3000 & 3200 \\
\hline Crude protein \% & 22 & 20 \\
\hline Lysine \% & 1.19 & 1.06 \\
\hline Methionine \% & 0.56 & 0.50 \\
\hline Methionine + cysteine \% & 1.23 & 1.23 \\
\hline Calcium \% & 0.97 & 0.76 \\
\hline Total phosphorus \% & 0.75 & 0.65 \\
\hline
\end{tabular}

': Supplied per kilogram of complete diet: vitamin A, 9,100 IU; vitamin D3, 1,850 IU; vitamin E, 18 IU; riboflavin, $7.0 \mathrm{mg}$; pantothenic acid, $15.0 \mathrm{mg}$; niacin, $36 \mathrm{mg}$; cobalamin, $10 \mu \mathrm{g}$; choline chloride, 300 $\mathrm{mg}$; biotin, $0.1 \mathrm{mg}$; folic acid, $0.6 \mathrm{mg}$; thiamine, $1.0 \mathrm{mg}$; pyridoxine, $3.0 \mathrm{mg}$; Fe, $75.0 \mathrm{mg}$; $\mathrm{nn}, 60.0 \mathrm{mg}$; $\mathrm{Mn}, 80.0 \mathrm{mg} ; \mathrm{l}, 0.4 \mathrm{mg}$; Cu, $4.0 \mathrm{mg}$; Se, 0.3mg.

\section{Birds and Housing}

Three hundred and fifty 1-day old male broilers (Ross 308), obtained from a commercial hatchery, were allocated to cages in electrically heated battery brooders. From 0 to $9 \mathrm{~d}$ of age, all birds were offered a common starter diet pelleted with a 3-mm diameter die and 3-mm length. On d 10, 300 birds were used in a completely randomized design for 42 days with 4 treatments in 3 replicates and 25 chicks in each replicate. Feed was offered ad libitum and water was freely available throughout the trial. The battery brooders and grower cages were housed in an environmentally controlled room with $20 \mathrm{~h}$ of fluorescent illumination per day. The temperature was maintained at $31^{\circ} \mathrm{C}$ on $\mathrm{d} 1$, and was gradually reduced to $22^{\circ} \mathrm{C}$ by 21 d of age.

\section{Chemical analysis}

All samples was determined using standard procedures (method 930.15; AOAC, 2005). 


\section{Performance data}

Body weights and feed intake were recorded on 10d, $21 \mathrm{~d}$ and $42 \mathrm{~d}$. Mortality was recorded daily. Feed per body-weight gain values were corrected for the body weight of any bird that died during the course of the experiment.

\section{Digestive tract measurements}

In all experiments, two birds, with body weights closest to the mean weight of the cage, were selected from each replicate cage and sacrificed by cervical dislocation. The live weight and weight of digestive tract segments from proventriculus to caeca of each bird were determined. The length of each intestinal segment was determined with a flexible tape on a wet glass surface to prevent inadvertent stretching. The length $( \pm 0.1 \mathrm{~cm})$ of the duodenum (from the pyloric junction to the distal-most point of insertion of the duodenal mesentery), the length of the jejunum (from the distal-most point of insertion of the duodenal mesentery to the junction with Meckel's diverticulum), the length of the ileum (from the junction with Meckel's diverticulum to ileocaecal junction) and the sum of the lengths from ostium to tip of each caeca were determined. Following division and freeing of each of these components from any adherent mesentery, their full and empty weights $( \pm 0.1 \mathrm{~g})$ were determined along with those of the proventriculus and gizzard.

\section{Statistical analysis}

The data were analysed by two-way analysis of variance (ANOVA) using the General Linear Models procedure of SAS (2004). Differences were considered to be significant at $P$ $<0.05$ and significant differences between means were separated by the Least Significant Difference (LSD) test.

\section{Results and Discussion:}

\section{Performance}

Mortality during the performance experiment was negligible. Only three out of the 300 birds died and the deaths were not related to any specific treatment. During the grower period (10 to $21 \mathrm{~d}$ ), weight gain was influenced $(P<0.05)$ by pellet length, with gain of birds fed pellets of 6-mm length being greater than that fed 3-mm length pellets (control group) (Table 2). Neither effects of pellet length were insignificant $(P>0.05)$ for feed intake (Table 3). Feeding longer pellets (5 and 6) $\mathrm{mm}$ decreased $(P<0.05$ ) feed per gain compared to control brids that fed to short $(3-\mathrm{mm})$ pellets. And there was no effect $(\mathrm{P}>$ 0.05 ) of pellet diameter for feed per gain (Table 4).

During the finisher ( 22 to $42 \mathrm{~d}$ ) and whole trial (10 to $42 \mathrm{~d}$ ) periods, effects of pellet length were insignificant $(P>0.05)$ for weight gain and feed intake (Table 2,3). pellet length had influence $(P<0.05)$ on feed per gain (Table 4). However, a significant $(P<0.05$, finisher period; $P<0.05$, whole trial period) pellet length effect was observed for feed per gain with increasing pellet length from 3- to 6- $\mathrm{mm}$, sothat decreased feed per gain at 6- $\mathrm{mm}$ pellet length. however, no effect of pellet length was observed for weight gain and feed intake. In this period, increasing the pellet length improved feed per gain in 4.5-mm diameter pellets. Cerrate et al. (2008) showed that at $7 \mathrm{~d}$, birds fed a maize-based diet 
pelleted with a $1.59 \mathrm{~mm}$ die had similar body weight to those fed a similar diet pelleted with a $2.38 \mathrm{~mm}$ die but higher body weight than birds fed the diet pelleted with a 3.17 $\mathrm{mm}$ die. Birds fed the diet pelleted with the $1.59 \mathrm{~mm}$ die consumed the greatest amount of feed during the 0-7 $\mathrm{d}$ period while those fed the diet pelleted with the $3.17 \mathrm{~mm}$ die consumed the least feed. The higher weight gain and feed intake with $1.59 \mathrm{~mm}$ diameter pellets were attributed to a more appropriate pellet size for the oral cavity of birds at this age (Moran, 1989) and an improved nutritive value due to higher gelatinisation of starch as the pellet die diameter is reduced (Heffner \& Pfost, 1973).

Table 2. Influence of pellet length (PL, mm) on the weight gain ( $\mathrm{g} /$ bird) of broilers ${ }^{1}$

\begin{tabular}{|c|c|c|c|}
\hline Treatment & $\begin{array}{c}\text { Grower } \\
\text { period } \\
(10 \text { to } 21) \mathrm{d}\end{array}$ & $\begin{array}{c}\text { Finisher period } \\
(22 \text { to } 42) \mathrm{d}\end{array}$ & $\begin{array}{c}\text { Whole trial period } \\
\text { (10 to 42) } d\end{array}$ \\
\hline T0 control & $627^{\mathrm{b}}$ & $1667^{\mathrm{NS}}$ & $2294^{\mathrm{NS}}$ \\
\hline $\mathrm{T} 1$ & $623^{\mathrm{b}}$ & 1628 & 2251 \\
\hline $\mathrm{T} 2$ & $650^{a}$ & 1673 & 2323 \\
\hline $\mathrm{T} 3$ & $640^{a}$ & 1710 & 2350 \\
\hline $\mathrm{SEM}^{2}$ & 8.2 & 44.5 & 51.2 \\
\hline
\end{tabular}

NS, not significant; * $P<0.05$.

1 Each value represents the mean of 3 replicates (25 birds per replicate).

2 Pooled standard error of mean.

Table 3. Influence of pellet length (PL, $\mathrm{mm}$ ) on feed intake $(\mathrm{g} /$ bird) of broilers

\begin{tabular}{|c|c|c|c|}
\hline Treatment & $\begin{array}{c}\text { Grower } \\
\text { period } \\
\text { (10 to 21) d }\end{array}$ & $\begin{array}{c}\text { Finisher period } \\
\text { (22 to 42) d }\end{array}$ & $\begin{array}{c}\text { Whole trial period } \\
\text { (10 to 42) d }\end{array}$ \\
\hline T0 control & $803^{\mathrm{NS}}$ & $3599 \mathrm{NS}$ & $4402^{\mathrm{NS}}$ \\
\hline T1 & 794 & 3581 & 4375 \\
\hline T2 & 816 & 3619 & 4435 \\
\hline T3 & 797 & 3566 & 4363 \\
\hline SEM $^{2}$ & 11.1 & 71.2 & 88.5 \\
\hline
\end{tabular}

NS, not significant; * $P<0.05$.

1 Each value represents the mean of 3 replicates (25 birds per replicate).

2 Pooled standard error of mean. 
Table 4. Influence of pellet length (PL, mm) on feed per gain (g feed/g gain) of broilers'

\begin{tabular}{|c|c|c|c|}
\hline Treatment & $\begin{array}{c}\text { Grower } \\
\text { period } \\
(10 \text { to } 21) \mathrm{d}\end{array}$ & $\begin{array}{c}\text { Finisher } \\
\text { period } \\
(22 \text { to } 42) \mathrm{d}\end{array}$ & $\begin{array}{c}\text { Whole trial } \\
\text { period } \\
(10 \text { to 42) } \mathrm{d}\end{array}$ \\
\hline T0 control & $1.280^{a}$ & $2.159 \mathrm{~b}$ & $1.919 \mathrm{ab}$ \\
\hline $\mathrm{T} 1$ & $1.275^{a}$ & $2.199 \mathrm{a}$ & $1.944^{\mathrm{a}}$ \\
\hline $\mathrm{T} 2$ & $1.255^{\mathrm{b}}$ & $2.163^{\mathrm{ab}}$ & $1.909 \mathrm{ab}$ \\
\hline $\mathrm{T} 3$ & $1.245^{\mathrm{b}}$ & $2.085^{\mathrm{c}}$ & $1.857^{\mathrm{b}}$ \\
\hline $\mathrm{SEM}^{2}$ & 0.0091 & 0.0121 & 0.0097 \\
\hline
\end{tabular}

NS, not significant; * $P<0.05$.

1 Each value represents the mean of 3 replicates (25 birds per replicate).

2 Pooled standard error of mean.

\section{Digestive tract measurements}

The effects of dietary treatments on the relative length and empty weight of the digestive tract of the broilers are shown in (Table 5,6). effects of pellet pellet length $(P<$ 0.05) were observed for relative length of duodenum. Increasing pellet length reduced the relative length of duodenum.

Neither effects were insignificant $(P>0.05)$ for relative length of jejunum, ileum and small intestine. While the effect of pellet length for the relative length of caeca $(P<0.05)$ was observed. Sothat increasing pellet length reduced the relative length of caeca.

And effect of pellet length was observed for relative weight of proventriculus $(P<0.05)$, with birds fed 3-mm length pellets having heavier proventriculus compared to those fed 4,5,6-mm length pellets. And effects were insignificant ( $P>0.05$ ) for relative weight of gizzard, small intestine and caeca, Other studies have demonstrated a similar phenomenon (Abdollahi et al.,2013), in which Increasing pellet diameter and pellet length reduced the relative length of duodenum, and Birds given 3-mm diameter pellets had heavier proventriculus compared to those given 4.76- $\mathrm{mm}$ diameter pellets, While the results incompatible with previous work reported no difference in the weight of these organs with particle sizes of 0.6 to $2.17 \mathrm{~mm}$ (Nir, et al., 1995).

Table 5. Influence of pellet length $(\mathrm{PL}, \mathrm{mm})$ on relative length $(\mathrm{cm} / \mathrm{kg}$ body weight) of the digestive tract of the broilers 1

\begin{tabular}{|l|c|c|c|c|c|}
\hline \multirow{2}{*}{$\begin{array}{l}\text { Treatmen } \\
\mathbf{t}\end{array}$} & \multicolumn{5}{|c|}{ Relative length } \\
\cline { 2 - 6 } & $\begin{array}{c}\text { Duodenu } \\
\mathbf{m}\end{array}$ & Jejunum & lleum & $\begin{array}{c}\text { Small } \\
\text { intestine2 }\end{array}$ & Caeca \\
\hline T0 control & $10.48^{\mathrm{a}}$ & $26.5^{\mathrm{NS}}$ & $27.1^{\mathrm{NS}}$ & $64.08^{\mathrm{NS}}$ & $7.25^{\mathrm{a}}$ \\
\hline T1 & $9.88^{\mathrm{b}}$ & 26.2 & 26.1 & 62.18 & $6.73^{\mathrm{b}}$ \\
\hline T2 & $9.4^{\mathrm{b}}$ & 26.5 & 26.5 & 62.74 & $6.86^{\mathrm{b}}$ \\
\hline T3 & $9.22^{\mathrm{c}}$ & 25.5 & 26.2 & 60.92 & $6.67 \mathrm{c}$ \\
\hline SEM $^{2}$ & 0.31 & 0.82 & 0.71 & 1.42 & 0.144 \\
\hline
\end{tabular}

NS, not significant; ${ }^{*} P<0.05$.

1 Each value represents the mean of 12 birds.

2 Small intestine $=$ duodenum + jejunum + ileum.

3 Pooled standard error of mean.

2020 November Edition | www.jbino.com | Innovative Association 
Table 6. Influence of pellet diameter (PD, mm) and pellet length (PL, mm) on empty weight $(\mathrm{g} / \mathrm{kg}$ body weight) of the digestive tract of the broilers'

\begin{tabular}{|c|c|c|c|c|}
\hline \multirow{2}{*}{ Treatment } & \multicolumn{4}{|c|}{ Relative empty weight } \\
\cline { 2 - 5 } & Proventriculus & Gizzard & $\begin{array}{c}\text { Small } \\
\text { intestine }\end{array}$ & Caeca \\
\hline T0 control & $2.84^{\mathrm{a}}$ & $6.02^{\mathrm{NS}}$ & $12.96^{\mathrm{NS}}$ & $0.88^{\mathrm{NS}}$ \\
\hline T1 & $2.5^{\mathrm{ab}}$ & 6.05 & 13.45 & 0.79 \\
\hline T2 & $2.29 \mathrm{~b}$ & 6.28 & 13.44 & 0.84 \\
\hline T3 & $2.36^{\mathrm{b}}$ & 6.33 & 12.71 & 0.84 \\
\hline SEM $^{2}$ & 0.17 & 0.21 & 0.42 & 0.05 \\
\hline
\end{tabular}

NS, not significant; * $P<0.05$.

1 Each value represents the mean of 12 birds.

2 Small intestine $=$ duodenum + jejunum + ileum.

3 Pooled standard error of mean.

\section{Conclusions}

Overall, the present data showed that increasing the pellet length from 3- to 6-mm during the grower period ( $d 10$ to 21) positively influenced the weight gain and feed per gain of broilers. While the weight gain response disappeared as the birds grew older. It was speculated that a better pellet quality per se is not the cause of improved feed per gain but rather the weight of intact pellets which may positively affect the productive energy. It seems plausible that using longer pellet lengths may have an additive effect on pellet quality.

\section{Acknowledgements}

I would like to acknowledge the University of Hama for financial support of this research. In addition, author wishes to thank the Agricultural organization of Hama province for providing the data used in this study. 


\section{References}

ABDOLLAHI, M.R., RAVINDRAN, V., WESTER, T.J., RAVINDRAN, G. \& THOMAS, D.V. (2013) The effect of manipulation of pellet size (diameter and length) on pellet quality and performance, apparent metabolisable energy and ileal nutrient digestibility in broilers fed maize-based diets. Animal Production Science, 53: 114-120. DOI

Amerah, A.M., Ravindran, V., Lentle, R.G. and Thomas, D.G. (2007) Influence of feed particle size and feed form on the performance, energy utilisation, digestive tract development, and digesta parameters of broiler starters. Poultry Science 86: 26152623. $\mathrm{DOI}$

AOAC (2005) Official Methods of Analysis, 18th edn (Washington DC, Association of Official Analytical Chemists).

Behnke, K.C. (2001) Factors influencing pellet quality. Feed Technology 5: 19-22.

Behnke, K.C. and Beyer, R.S. (2002) Effect of feed processing on broiler performance. VIII. International Seminar on Poultry Production and Pathology, Santiago, Chile. Semantic Scholar

Calet, C. (1965) The relative value of pellets versus mash and grain in poultry nutrition. Worlds Poult. Sci. J.21:23-52. DOI

CerRate, S., WANG, Z., COTO, C., YAN, F. \& WALDROUP, P.W. (2008) Effect of pellet diameter in broiler prestarter diets on subsequent performance. International Journal of Poultry Science, 7: 1138-1146. DOI

CERRATE, S., WANG, Z., COTO, C., YAN, F. \& WALDROUP, P.W. (2009) Effect of pellet diameter in broiler starter diets on subsequent performance. Journal of Applied Poultry Research, 18: 590-597. DOI

Corzo, A., Mejia, L. and Loar II, R.E. (2011) Effect of pellet quality on various broiler production parameters. Journal of Applied Poultry Research 20: 68-74. DOI

CUTLIP, S.E., HOTT, J.M., BUCHANAN, N.P., RACK, A.L., LATSHAW, J.D. \& MORITZ, J.S. (2008) The effect of steam-conditioning practices on pellet quality and growing broiler nutritional value. Journal of Applied Poultry Research, 17: 249-261. DOI

Denbow DM.(2000) Gastrointestinal anatomy and physiology.In: GC Whittow (editor). Sturkie's Avian Physiology. Academic Press, London. p. 299-325. DOl

DOZIER, W.A. (2003) Optimising the conditioning process. Feed Management, 54: 23-27.

Goodband, R.D., Tokach, M.D. and Nelssen, J.L. (2002). The effects of diet particle size on animal performance. MF-2050 Feed Manufacturing, Department of Grain Science and Industry, Kansas State University, Manhattan, KS, USA. pp: 1-6. pdf

HEFFNER, L.E. \& PFOST, H.B. (1973) Gelatinisation during pelleting. Feedstuffs, 45: 32-33.

Hott, J.M., Buchanan, N.P., Cutlip, S.E. and Moritz, J.S. (2008) The effect of moisture addition with a mold inhibitor on pellet quality, feed manufacture, and broiler performance. Journal of Applied Poultry Research 17: 262-271. DOI

JENSEN, L.S., MERRILL, L.H., REDDY, C.V. \& MCGINNIS, J. (1962) Observations on eating patterns and rate of food passage of birds fed pelleted and unpelleted diets. Poultry Science, 41: 1414-1419. DOI 
JONES, F.T., ANDERSON, K.E. \& FERKET, P.R. (1995) Effect of extrusion on feed characteristics and broiler chicken performance. Journal of Applied Poultry Research, 4: 300-309. $\underline{\mathrm{DOl}}$

Kilburn, J., and H. M. Edwards Jr.. (2001) The response of broilers to the feeding of mash or pelleted diets containing maize of varying particle sizes. Br. Poult. Sci. 42:484-492. DOI LÖWE, R. (2005) Judging pellet stability as part of pellet quality. Feed Technology, 9: 15-19. Macari M, Furlan RL, Gonzales E.(1994) Fisiologia aviária aplicada a frangos de corte. Jaboticabal: Funep/Unesp, 294p.

Magro N.(1999) Variação da granulometria das rações em frangos de corte machos, de 21 aos 42 dias de idade.[Dissertação]. Universidade Federal do Rio Grande do Sul. Porto Alegre (RS).

McKinney, L. J., and R. G. Teeter. (2004) Predicting effective caloric value of nonnutritive factors: I. Pellet quality and II. Prediction of consequential formulation dead zones. Poult. Sci. 83:1165-1174. DOI

Moran, E.T. (1989) Effect of pellet quality on the performance of meat birds. Recent Advances in Animal Nutrition, Butterworth, London.

MORITZ, J.S., BEYER, R.S., WILSON, K.J. \& CRAMER, K.R. (2001) Effect of moisture addition at the mixer to a corn-soybeanbased diet on broiler performance. Journal of Applied Poultry Research, 10:347-353. DOI

MORITZ, J.S., CRAMER, K.R., WILSON, K.J. \& BEYER, R.S. (2003) Feed manufacture and feeding of rations with graded levels of added moisture formulated to different energy densities. Journal of Applied Poultry Research, 12: 371-381. DOI

Nir IG, Shefet Y, Aroni G.(1994a) Effect of of grain particle size on performance. 1.Corn. Poultry Science; 73: 45-49. DOI

Nir, I., TWINA, Y., GROSSMAN, E. \& NITSAN, Z. (1994b) Quantitative effects of pelleting on performance, gastrointestinal tract and behaviour of meat-type chickens. British Poultry Science, 35: 589-602. DOI

Nir I, Hillel R, Ptichi I. (1995) Effect of particle size on performance. Grinding pelleting interactions. Poultry Science; 74:771-783. DOI

Portella, F. J., L. J. Caston, and S. Leeson. (1988) Apparent feed particle size preference by broilers. Can. J. Anim. Sci. 68:923-930. pdf

ROSS (2007). Ross 308 Broiler: Nutrition Specification, June 2007 (Newbridge, Midlothian, Scotland, UK, Ross Breeders Limited).

SAS INSTITUTE (2004) SAS® Qualification Tools User's Guide. Version 9.1.2. SAS Institute Inc., Cary, NC.

Scheideler, S.E. (1991) Pelleting is important for broilers. Proceeding of the North Carolina Poultry Nutrition Conference, Carolina Feed Industry Association, Sanford, NC.

Skinner-Noble, D. O., L. J. McKinney, and R. G. Teeter. (2005) Predicting effective caloric value of nonnutritive factors: III. Feed form affects broiler performance by modifying behavior patterns. Poult. Sci. 84:403-411. DOI 
SVIHUS, B., KLØVSTAD, K.H., PEREZ, V., ZIMONJA, O., SAHLSTROM, S., SCHUlleR, R.B., JEKSRUD, W.K. \& PRESTLØKKEN, E. (2004) Physical and nutritional effects of pelleting of broiler chicken diets made from wheat ground to different coarsenesses by the use of roller mill and hammer mill. Animal Feed Science and Technology, 117: 281-293. DOI

Thomas, M., van Vliet, T. and van der Poel, A.F.B. (1998) Physical quality of pelleted animal feed: 3. Contribution of feedstuff components. Animal Feed Science and Technology 70: 59-78. DOI 